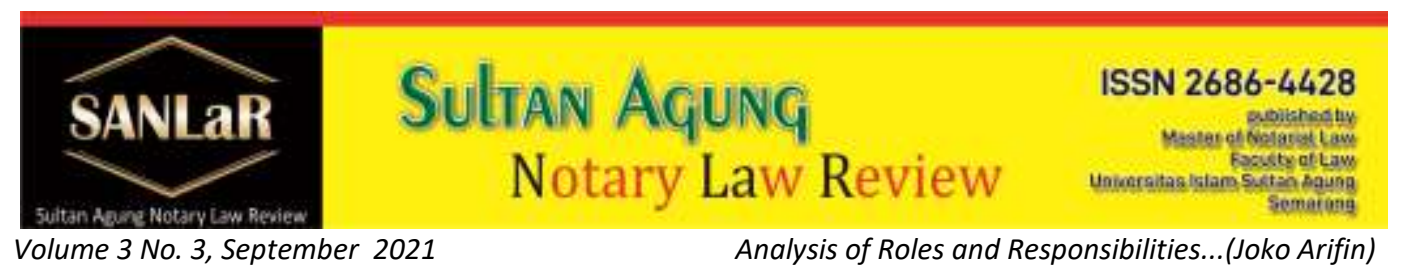

\title{
Analysis of Roles and Responsibilities of Notaries in the Establishment of Cooperatives
}

\author{
Joko Arifin*) \\ ${ }^{*}$ Faculty of Law, Universitas Islam Sultan Agung (UNISSULA) Semarang, E-mail: \\ jokoarifin2021@gmail.com
}

Abstract. This research method is a qualitative method, with an empirical juridical approach. The specification of this research is descriptive analysis. The data sources used are primary and secondary data obtained through interviews and literature studies, while the data analysis is descriptive analytic. The purpose of this study is to analyze: 1) Implementation of the Deed of Establishment of Cooperatives in Semarang City. 2). The role and responsibilities of a Notary as a Maker of the Deed of Establishment of a Cooperative Business Entity in the City of Semarang. The results of the study concluded: 1) The implementation of the making of the Deed of Establishment of a Cooperative in the City of Semarang, starting from the preparation stage for the formation, the preparation stage for the formation meeting, namely by conducting cooperative counseling, the formation meeting stage attended by a Notary, the application stage to obtain the legalization of the legal entity rights of the Cooperative. Approval is carried out by the Department of Industry, Trade, Cooperatives and MSMEs to examine the articles of association and check the existence of cooperatives. Implementation of the Deed of Establishment of Cooperatives in the City of Semarang, in accordance with Article 1 and Article 15 of Act No. 2 of 2014, as well as in Article 1 paragraph (4) of the Decree of the State Minister of Cooperatives and Small and Medium Enterprises of the Republic of Indonesia Number: 98/KEP/M KUKM/IX/2004 concerning Notary as Cooperative Deed Maker. 2) The role and responsibility of the Notary as the Maker of the Deed of Establishment of the Cooperative Business Entity in the City of Semarang is as the maker of the deed of establishment of the Cooperative Business Entity. The notary has the right/legal standing in making the deed of establishment of a cooperative legal entity. Only Notaries who have the right/legal standing in making a deed of establishment of a cooperative legal entity are only certain notaries who have attended briefings in making a deed in connection with a cooperative legal entity and already have a certificate/brevet as a Notary as the Cooperative Deed Making Officer (PPAK).

Keywords: Roles; Responsibilities; Notary; Deed; Cooperative. 


\section{Introduction}

As a means to achieve a just and prosperous society, cooperatives cannot be separated from its foundation, namely Pancasila. Specificity of cooperatives The principle of kinship as the basic joint in building the national economic system is further realized in the form of "cooperatives" as a people's economic movement to create an advanced, just and prosperous society. ${ }^{1}$

Cooperatives are a form of corporate organization where the main goal is not to seek profit but to seek the welfare of its members. Cooperatives as an association for the common welfare, conduct business and activities in the field of meeting the common needs of its members. People's businesses in the form of cooperatives that prioritize the principle of togetherness are the main differences with other forms of business, including limited liability companies based on individual principles, especially in share ownership and stock management, which are the main assets in developing cooperatives as business entities in accordance with the spirit of the Indonesian nation. ${ }^{2}$

The establishment of a cooperative is required or using a Notary deed with strong legal force. The existence of this legal force is the basis for cooperative activities, in order to have protection for the institution and its management. One of the biggest obstacles for the development of cooperatives is the lack of accurate legal standing of cooperatives, in terms of granting legal entities, the authority to provide cooperative legal entities is the Minister of Cooperatives. In carrying out this authority, the Minister may delegate his authority to the Officials and Regional Heads to provide Cooperative Legal Entities. ${ }^{3}$

The new regulation issued in the form of Regulation of the Minister of Law and Human Rights (Permenkumham) of the Republic of Indonesia Number 4 of 2014 concerning Procedures for Submitting Applications for Legal Entities and Approval of the Articles of Association as well as Submission of Notification of Amendments to the Articles of Association and Amendments to Limited Company Data which was updated by Permenkumham Number 1 of 2016 concerning Amendments to the Regulation of the Minister of Law and Human Rights Number 4 of 2014 concerning Procedures for Submitting Applications for Legal Entity and Approval of the Articles of Association as well as Submission of Notification of Amendments to the Articles of Association and Changes in Limited Company Data made through electronic media (Online).

\footnotetext{
${ }^{1}$ Moh. Hatta, 1954, Meninjau Masalah Koperasi, Pembangunan, Jakarta, p. 25

2 Ninik Widiyanto, 1992, Koperasi dan Perkonomian Indonesia, Rineka Cipta, Jakarta, p.76.

${ }^{3}$ LPS21, 2001, Kajian Akademik Rancangan Undang-undang Koperasi, Jakarta, p. 64.
} 
Notaries as public officials are one of the state organs equipped with legal authority to provide public services ${ }^{4}$ to the community, especially in making authentic deeds as perfect evidence regarding legal actions in the civil sector. ${ }^{5}$

To make an Authentic Deed, a Notary must follow the rules that have been regulated in the law. Act No. 30 of 2004 concerning the Position of Notary jo. Act No. 2 of 2014 concerning the Notary Position which is the legal basis for the Notary Position, has determined step by step what a Notary must do if he makes an authentic deed. These steps (among others hearing the parties express their will, then reading the contents of the deed to the parties, signing the deed, etc.) are specifically made by lawmakers to ensure that what is written in the deed contains what is desired. the parties. ${ }^{6}$ One very important role is the existence of a Notary in this case is the Notary of the Cooperative Deed Maker who will express the will of the parties in a deed of establishment of the cooperative.

The city of Semarang is one of the cities affected by the COVID-19, which not only has an impact on health, but also the economy. Therefore, the Semarang City government provides assistance and fully supports the development of MSMEs and Cooperatives. Cooperatives are one of the factors that can stimulate the economy, especially for the lower middle class, for that growth must always be supervised. Because together with the growth and development of cooperatives will definitely be followed by economic growth in the city of Semarang. The establishment of this cooperative cannot be separated from the role of various parties, including one of them is a notary.

\section{Research Methods}

The approach method used in this study is a normative juridical approach. Primary and secondary data sourcesobtained by interview method and literature review (study document). The data that has been collected both from field research and library research were analyzed using descriptive analysis methods.

\footnotetext{
${ }^{4}$ Deen, Thaufiq., Ong Argo Victoria \& Sumain. (2018). Public Notary Services In Malaysia. JURNAL AKTA: Vol. 5, No. 4, 1017-1026. Retrieved from http://jurnal.unissula.ac.id/index.php/akta/article/view/4135

${ }^{5}$ N.G Yudara, Notaris dan Permasalahannya (Pokok-Pokok Pemikiran Di Seputar Kedudukan dan Fungsi Notari Serta Akta Notaris Menurut Sistem Hukum Indonesia). Majalah RenvoiNomor 10.34 III, Issue 3 March 2006, p. 72

${ }^{6}$ Tan Khong Kie (b), 2000, Buku II Studi Notarisat Serba Serbi Praktek Notaris, ed.1, Ikhtiar Baru Van Hoeve, Jakarta, p. 261
} 


\section{Results and Discussion}

\subsection{Implementation of the Deed of Establishment of Cooperatives in the City of Semarang}

Base Law on Establishment of Cooperatives Government Regulation Number 4 of 1994 concerning Requirements and Procedures, namely

a. Ratification of the Deed of Establishment and Amendment to the Articles of Association; Regulation of the State Minister for Cooperatives and Small and Medium Enterprises of the Republic of Indonesia Number: 01/Per/M.KUKM/I/2006 dated January 9, 2006 concerning Implementation Guidelines for the Establishment, Ratification of the Deed of Establishment and Amendment to the Articles of Association of Cooperatives;

b. Decree of the State Minister of Cooperatives and Small and Medium Enterprises of the Republic of Indonesia Number: 98/Kep/KEP/KUKM/X/2004 dated September 24, 2004 concerning Notaries as Makers of the Deed of Establishment of Cooperatives;

Stages of Submission of Cooperatives with Legal Entities include:

a. Establishment Meeting

1) Primary Cooperatives are attended by a minimum of 20 people, and for Secondary Cooperatives a minimum of 3 (three) Cooperatives that have legal entities represented by their proxies.

2) Attended by Officials of the Small and Medium Enterprises Cooperatives Office of Semarang City;

3) The topics discussed at the meeting included:

a) The name and position of the cooperative;

b) Membership;

c) Business to be carried out;

d) Capital;

e) Election of Managers and Supervisors;

f) Concept of Articles of Association/Budgets;

b. Submission of Documents for Ratification of the Deed of Establishment of Cooperatives. Condition :

1) Application for Legalization of Cooperative Establishment Deed with a stamp duty of Rp. 6.000,-

2) Excerpts of the Minutes of the Meeting of the Establishment/Formation of Cooperatives;

3) Initial Balance Sheet;

4) Member Deposit Certificate

5) Attendance list for the Establishment Meeting. 

6) List of Founder's Names;
7) Copy of Founder's ID Card;
8) Deed of Establishment from a Notary;
9) Initial Plan of Business Activities;
10) Biodata of Managers and Supervisors;
11) Certificate of Office status;
12) Office Inventory List

\section{c. Field Overview.}

Checked Into the Field (Cooperative Secretariat) by the Cooperative Legal Entity Team. Field Review Team Results:

1) If it meets the requirements, both administrative and complete in the field, a Decision Letter on Legal Entity is issued.

2) If there is a shortage, it must be completed first, until the maximum time limit is 3 months, if it is more than 3 months then the file is returned to the Cooperative.

The Ministry of Cooperatives and Small and Medium Enterprises has actually waived the cost of a special cooperative establishment deed for microenterprises, which is the result of a collaboration with the Indonesian Notary Association (INI). This is because this component is the highest and most burdensome cost, which ranges from Rp. 1.5 million to Rp. 3 million. Until now, most of the Cooperatives and Micro Business Offices are still free of charge for the establishment of a cooperative deed. There is no charge for the Legalization of the Cooperative Establishment Deed.

Ratification of the Deed of Establishment of Cooperatives Based on Article 6 paragraph (1) of the Regulation of the State Minister of Cooperatives and Small and Medium Enterprises of the Republic of Indonesia Number: 01/Per/M.KUKM/I/2006 concerning Implementation Guidelines for the Establishment, Ratification of the Deed of Establishment and Amendments to the Articles of Association of Cooperatives, the Cooperative founders or their proxies can prepare the Cooperative's deed of establishment themselves or through the assistance of a Notary who makes the Cooperative Deed.

The founders or their proxies submit a request for approval in writing to the official authorized to ratify the deed of establishment of the Cooperative. Based on Article 7 paragraph (1) of the Regulation of the State Minister of Cooperatives and Small and Medium Enterprises of the Republic of Indonesia Number: 01/Per/M.KUKM/I/2006 concerning Implementation Guidelines for the Establishment, Ratification of the Deed of Establishment and Amendment to the Articles of Association of Cooperatives, if the Deed of Establishment of a 
Cooperative is drawn up by a Notary, then the request for approval of the deed of establishment of the Cooperative is submitted by attaching:

1) 1 (one) copy of the Cooperative's deed of establishment with sufficient stamp duty;

2) data on the deed of establishment of the Cooperative drawn up and signed by a Notary;

3) a letter of evidence of the availability of capital in the amount of at least the amount of the principal savings and mandatory savings that must be repaid by the founders;

4) Cooperative business activity plan for at least the next three years and Cooperative Budget and Income Plan;

5) other documents required in accordance with the laws and regulations.

In the event that the deed of establishment of the Cooperative is made by the founders of the Cooperative, the request for ratification of the deed of establishment of the Cooperative according to Article 7 paragraph (2) of the Regulation of the State Minister of Cooperatives and Small and Medium Enterprises of the Republic of Indonesia Number: 01/Per/M.KUKM/I/2006 concerning Instructions Implementation of the Establishment, Ratification of the Deed of Establishment and Amendment to the Articles of Association of the Cooperative, by attaching:

1) 2 (two) copies of the deed of establishment of the Cooperative, one of which has sufficient stamp duty;

2) data on the deed of establishment of the Cooperative drawn up and signed by the proxies of the founders;

3) minutes of the cooperative formation meeting;

4) power of attorney;

5) a letter of proof of the availability of capital in the amount of at least the amount of the principal savings and mandatory savings that must be repaid by the founders;

6) Cooperative business activity plan for at least the next three years and Cooperative Budget and Income Plan;

7) attendance list for the establishment meeting;

8) for primary cooperatives attach a photocopy of the Identity Card (KTP) of the founders;

9) for secondary Cooperatives, attach the decision of the meeting of members of each Cooperative concerning the approval of the establishment of secondary Cooperatives and a photocopy of the deed of establishment and articles of association of each founding Cooperative.

If what is requested for approval is the Deed of Establishment of a Savings and Loan Cooperative or a Cooperative that has a Savings and Loan Unit, then based 
on the Decree of the Minister of Cooperatives, Small and Medium Enterprises Number: 351/KEP/M/XII/1998 concerning Guidelines for the Implementation of Savings and Loans Business Activities by Cooperatives, there is an additional attachments as follows:

1) Proof of deposit of own capital at the beginning of the establishment of a Primary Savings and Loans Cooperative or Primary Cooperative which has a Savings and Loan Unit of at least Rp. 15,000,000 (fifteen million rupiah) and Rp. 50,000,000 (fifty million rupiah) for establishment Secondary KSP and USP on Secondary Cooperatives. The equity deposit consists of, among others, principal savings and mandatory savings as well as equity participation which is realized in the form of deposits at Government Banks which are deposited on behalf of the Minister of Cooperatives, Small and Medium Enterprises cq the Head of the KSP or Cooperative concerned.

2) Work Plan for at least 1 (one) year.

3) Principal administration and bookkeeping include: application form to become a member, application form for resignation as a member, member list book, member savings list book, savings and/or time deposit forms, loan administration forms provided, loan agreement forms.

4) Name and curriculum vitae of the prospective manager by attaching:

a) Savings and loan training certificate and/or certificate of having participated in a savings and loan business internship/or certificate of experience working in the financial sector.

b) A certificate of good behavior from the competent authority stating that the person concerned has never committed a disgraceful act or been punished for being proven to have committed a criminal offense in the financial sector or other criminal acts ${ }^{7}$.

c) The statement letter does not have a family relationship with the Management up to the 1st (one) degree.

d) The list of work facilities includes, among others: offices, desks and desk chairs, calculators for storing money, places for storing administrative books and bookkeeping.

e) Work agreement letter between the Cooperative Management and the Manager/ Manager/ Board of Directors. If the application for ratification of the Cooperative's deed of establishment has been completed, the authorized official shall provide a letter of receipt to the founder or his proxies.

Based on Article 8 paragraph (1) of the Regulation of the State Minister of Cooperatives and Small and Medium Enterprises of the Republic of Indonesia Number: 01/Per/M.KUKM/1/2006 concerning Implementation Guidelines for the

\footnotetext{
${ }^{7}$ A Chuasanga, Ong Argo Victoria. (2019). Legal Principles Under Criminal Law in Indonesia Dan Thailand, Jurnal Daulat Hukum, Vol 2, No 1 (2019) http://jurnal.unissula.ac.id/index.php/RH/article/view/4218
} 
Establishment, Ratification of the Deed of Establishment and Amendment to the Articles of Association of Cooperatives that the authorized official is obliged to carry out research on the articles of association to be ratified. In addition, it also conducts field checks on Cooperatives to be established, especially those related to domicile/address, management, business being run and membership. If the results of the research and checking are judged that the cooperative is worthy of ratification, the official shall ratify the deed of establishment of the cooperative. The ratification of the deed of establishment of the Cooperative is stipulated within a period of no later than three months from the receipt of the request for complete ratification.

\subsection{Roles and Responsibilities of Notary as Maker of Deed of Establishment of Cooperative Business Entity in Semarang City}

1. The Role of the Notary as the Maker of the Deed of Establishment of a Cooperative Business Entity in the City of Semarang

Article 1 paragraph (1) of Act No. 30 of 2004 states that a Notary is a public official who is authorized to make authentic deeds and other authorities as referred to in this Law. From this definition, it can be interpreted that authentic deeds must be made by a Notary: ${ }^{8}$

\section{a. If desired by them or interested parties \\ b. If it is regulated by law, it must be stated in an authentic deed.}

According to Semarang Notary Ngadino in Article 2 paragraph (1) of the Decree of the State Minister of Cooperatives and Small and Medium Enterprises of the Republic of Indonesia Number: 98/KEP/M.KUKM/IX/2004 concerning Notaries as Cooperative Deed Makers states that: parties who work based on the code of ethics of their positions and provide services to the community in the process of establishment, amendments to the articles of association and other deeds related to cooperative activities. The provisions mentioned above explain that a Notary is authorized to make a cooperative deed because of his position as a public official who has the main task of making an authentic deed, as evidence that a certain legal act has been carried out in the establishment process. amendments to the articles of association as well as other deeds related to cooperative activities to apply for approval to the authorized official. The notary's authority includes 4 things, namely: ${ }^{9}$

\footnotetext{
${ }^{8}$ R. Soegondo Notodisoerjo, Hukum Notariat di Indonesia Suatu Penjelasan, PT Raja Grafindo Persada, Jakarta , 1993, p.48

9 Lumban Tobing, 1983, Peraturan Jabatan Notaris, Erlangga Jakarta Penerbit, p. 48.
} 
a. The notary must be authorized as far as the deed is made;

b. The notary must be authorized as long as it concerns the people, for whose interest the deed was made;

c. The notary must be authorized as long as it concerns the place where the deed was made;

d. The notary must be authorized as long as it is about the time of making the deed

The results of the interview with Semarang Notary Ngadino in Article 1 paragraph (4) of the Decree of the State Minister for Cooperatives and Small and Medium Enterprises of the Republic of Indonesia Number: 98/KEP/M.KUKM/IX/2004 concerning Notaries as Cooperative Deed Makers state that: is a public official who is appointed based on the Notary Position Regulations who are authorized, among others, to make a deed of establishment, deed of amendment to the articles of association and other deeds related to cooperative activities.

Another obligation of a notary is to issue a copy of the cooperative deed based on Article 16 paragraph (1) letter c of Act No. 30 of 2004 concerning the Position of a Notary. A copy of the cooperative deed is a copy of the deed issued by a notary after the minutes of the cooperative deed are signed by the appearers then a copy of the same sound as the minutes is issued which is only signed by the notary on a seal and stamped with the position of notary. A copy of the deed issued by a notary is for the benefit of the appearers as evidence that a legal action related to the cooperative has been carried out and as one of the requirements for the establishment of the cooperative, amendments to the articles of association and the dissolution of the cooperative.

2. Responsibilities of Notary as Maker of Deed of Establishment of Cooperative Business Entity in Semarang City

Notaries as public officials carry out the mandate from 2 (two) sources, namely: ${ }^{10}$

a. Members of the public who become the notary's client want the notary to make an authentic deed for those concerned by implicitly making a mandated sentence "fulfill all formal requirements for validity as an authentic deed", and

b. The mandate is in the form of a legal order (indirectly) to a notary so that certain legal actions are poured and stated with an authentic deed, it implies that the notary is bound and obliged to obey the regulations that require it to be valid as an authentic deed.

${ }^{10}$ Media Notariat, October 1995 Edition, penerbit Ikatan Notaris Indonesia, p. 55 
Notary Ngadino in the city of Semarang said that the Notary in his position as a cooperative deed maker and because of his position was responsible for the authenticity of the deeds he made, ${ }^{11}$ This is based on the provisions of Article 2 paragraph (2) of the Decree of the State Minister of Cooperatives and Small and Medium Enterprises of the Republic of Indonesia Number: 98/KEP/M.KUKM/IX/2004 concerning Implementation Guidelines for the Establishment, Ratification of the Deed of Establishment and Amendment to the Articles of Association of Cooperatives. to the parties who have an interest in the deed he made to (clients) including the parties who made the deed related to the cooperative in the following matters: ${ }^{12}$

a. It is expressly determined by the Notary Position Regulations (now the Notary Position Law).

b. Because a deed made does not meet the requirements regarding the form (gebrek in de vorm), is canceled before the court or is considered to only be valid as a deed made under the hand,

c. In all cases, according to the provisions of Article 1365, Article 1366 and Article 1367 of the Civil Code, there is an obligation to pay compensation.

The provisions of Article 41, Article 44, Article 48, Article 49, Article 50, Article 51 and Article 52 of the Notary Position Act if not fulfilled by the Notary who made the cooperative deed which resulted in the cooperative deed he made only having the power of proof as a private deed or a deed becomes null and void can be a reason for the party suffering losses to demand reimbursement of costs, compensation and interest to a notary.

\section{Closing}

Implementation of the Deed of Establishment of Cooperatives in the City of Semarang, namelybased on Law on Establishment of Cooperatives Government Regulation Number 4 of 1994 concerning Requirements and Procedures, namely Establishment Meeting, Submission of Documents for Legalization of Deed of Establishment of Cooperatives, Field Review, Ratification of Deed of Establishment of Cooperatives, Amendment to Articles of Association, Dissolution. Approval is carried out by the Department of Industry, Trade, Cooperatives and MSMEs to examine the articles of association and check the existence of cooperatives. Implementation of the Deed of Establishment of Cooperatives in the City of Semarang, in accordance with Article 1 and Article 15 of Act No. 2 of 2014, as well as in Article 1 paragraph (4) of the Decree of the

\footnotetext{
${ }^{11}$ Result of interview with Notary Ngadino in Semarang 01-14-2021

12 Lumban Tobing, Ibid, p. 325.
} 
State Minister of Cooperatives and Small and Medium Enterprises of the Republic of Indonesia Number: 98/KEP/M KUKM/IX/2004 concerning Notary as Cooperative Deed Maker. The role and responsibility of the Notary as the Maker of the Deed of Establishment of the Cooperative Business Entity in the City of Semarang is as the maker of the deed of establishment of the Cooperative Business Entity. The notary has the right/legal standing in making the deed of establishment of a cooperative legal entity. Only Notaries who have the right/legal standing in making a deed of establishment of a cooperative legal entity are only certain notaries who have attended briefings in making a deed in connection with a cooperative legal entity and already have a certificate/brevet as a Notary as the Cooperative Deed Making Officer (PPAK).

\section{References}

Journals:

[1] A Chuasanga, Ong Argo Victoria. (2019). Legal Principles Under Criminal Law in Indonesia Dan Thailand, Jurnal Daulat Hukum, Vol 2, No 1 (2019) http://jurnal.unissula.ac.id/index.php/RH/article/view/4218

[2] Deen, Thaufiq., Ong Argo Victoria \& Sumain. (2018). Public Notary Services In Malaysia. JURNAL AKTA: Vol. 5, No. 4, 1017-1026. Retrieved from http://jurnal.unissula.ac.id/index.php/akta/article/view/4135

Books:

[1] Amiruddin, Pengantar Metode Penelitian Hukum, Rajagrafindo Persada, Jakarta, 2012.

[2] Arifin Sitio, Halomoan Tamba, Koperasi - Teori \& Praktek, Erlangga, Jakarta, 2001.

[3] Budi Untung, Hukum Koperasi Dan Peran Notaris Indonesia, Andi Penerbit, Yogyakarta 2005.

[4] Burhan Ashosofa, 2000, Metode Penelitian Hukum, Rineka Cipta, Jakarta

[5] Frans Hendra Winarta, 2003, "Persepsi Sebagian Masyarakat Terhadap Profesi Hukum di Indonesia" Media Notariat, CV. Pandeka Lima, Jakarta

[6] Habib Adjie, 2003, Tebaran Pemikiran Dalam Dunia Notaris dan PPAT, "Penegakan Etika Profesi Notaris Dari Perspektif Pendekatan System,"Lembaga Kajian Notaris dan PPAT Indonesia, Surabaya

[7] Hendrojogi, Kopersi - Asas-Asas Teori Dan Praktek, Rajagrafindo Persada, Jakarta, 2002.

[8] Irsyadul Anam Malaba, "Pluralitas Organisasi Notaris di antara Hak, Kebutuhan, Inefiensi dan Tafsir Pemerintah". Jurnal Renvoi, Nomor 2. 26. III Tahun Ketiga 2005

[9] LPS21, 2001, Kajian Akademik Rancangan Undang-undang Koperasi, Jakarta 
[10] Lutfi Effendi, 2004, Pokok-pokok Hukum Administrasi, Edition 1 Print. Kedua, Bayumedia Publising, Malang

[11] M.Gondo Ratangin, 2017, Pergeseran Kekuatan Hukum Akta Pendirian Koperasi Serta Kewenangan Notaris Sebagai Pejabat Pembuat Akta Koperasi, Tesis Undip Semarang

[12] Max Weber, 2008, Mastering Public Administration, Second Edition, CQ Press, Washington

[13] Mukti Fajar dan Yulianto, 2010, Dualisme Penelitian Hukum Normatif dan Empiris, Pustaka Pelajar, Yogyakarta

[14] N.G Yudara, Notaris dan Permasalahannya (Pokok-Pokok Pemikiran Di Seputar Kedudukan dan Fungsi Notari Serta Akta Notaris Menurut Sistem Hukum Indonesia). Majalah RenvoiNomor 10.34 III, Edition 3 Maret 2006

[15] Peter Mahmud Marzuki, 2010, Penelitian Hukum, Kencana Prenada Media Group, Jakarta

[16] Purnama TioriaSianturi, 2008, Perlindungan Hukum Terhadap Pembeli Barang JaminanTidakBergerak MelaluiLelang, PenerbitMandarMaju ,Bandung

[17] Soerjono Soekanto dan Sri Mamadji, 2009, Penelitian Hukum Normatif: Suatu Tinjauan Singkat, RajaGrafindo Persada, Jakarta

[18] Sudarsono, Edilius, Koperasi - Dalam Teori Dan Praktek, Rineka Cipta, Jakarta, 2002.

[19] Sutantya Rahardo Hadhikusuma, Hukum Koperasi Indonesia, Rajagrafindo

Regulation:

Act No. 30 of 2004 concerning the Position of a Notary.

Act No. 25 of 1992 About Cooperatives. 